\title{
Morphological traits and genetic parameters of Hippeastrum hybridum
}

\author{
Mohammad Hossein Azimi ${ }^{* *}$ (1) and Maryam Karimi Alavijeh² (1) \\ 'Ornamental Plants Research Center (OPRC), Horticultural Sciences Research Institute (HSRI), Agricultural Research, \\ Education and Extension Organization (AREEO), Mahallat, Iran. \\ ${ }^{2}$ Ornamental Plants Research Center (OPRC), Horticultural Sciences Research Institute (HSRI), Agricultural Research, \\ Education and Extension Organization (AREEO), Department Genetic and Breeding, Mahallat, Iran.
}

\begin{abstract}
Amaryllis is a bulbous flowering plant that has attracted many florists in Iran in recent years. The present study aimed to explore genetic diversity and quantitative and qualitative yield of imported cultivars and promising genotypes of amaryllis. The research used 16 genotypes based on a randomized complete block design with three replications in the Ornamental Plants Research Center in Iran (2017-2018). Based on the guideline of the International Union for the Protection of New Varieties of Plants (UPOV), 17 major traits were selected to assess the genotypes. The differences in genotypes showed a wide diversity in all traits among them. The highest general heritability was observed in flowering period (93.86\%) and leaf length $(91.24 \%)$ and the lowest in the number of florets per branch $(20.37 \%)$. Overall, most traits had high heritability. The highest number of flowering branches, flowering period, floret length, stalk diameter, leaf number, and leaf length were obtained from 'Moscow'. The highest peduncle length, floret width, and flowering period were observed in the promising genotype 'OPRC-202'. The flower form was double in 'Cherry Nymph', 'Dancing Queen', and 'OPRC-204', miniature in 'Baby Star', and simple (single-flower) in the other genotypes. Based on the results, the promising genotypes 'OPRC-202' and 'OPRC-204' have a high potential to be introduced as new competitive cultivars in domestic and international markets. The promising genotypes and cultivars were categorized in four groups. The results showed that major of the diversity in the traits was due to genetic factors and the effect of the environment on these traits was less. Keywords: amaryllis, flowering period, genetic diversity, genotype, heritability.
\end{abstract}

\section{Resumo}

Características morfológicas e parâmetros genéticos de Hippeastrum hybridum

Amaryllis é uma planta bulbosa que atraiu muitos floristas no Irã nos últimos anos. O presente estudo teve como objetivo explorar a diversidade genética e a produção quantitativa e qualitativa de cultivares importadas e genótipos promissores de amarílis. A pesquisa utilizou 16 genótipos baseados em um delineamento de blocos completos casualizados com três repetições no Centro de Pesquisa de Plantas Ornamentais no Irã (2017-2018). Com base na diretriz da União Internacional para a Proteção de Novas Variedades de Plantas (UPOV), foram selecionadas 17 características principais para avaliar os genótipos. As diferenças nos genótipos mostraram grande diversidade em todas as características entre eles. A maior herdabilidade geral foi observada no período de floração $(93,86 \%)$ e comprimento das folhas $(91,24 \%)$ e a menor no número de flores por ramo $(20,37 \%)$. No geral, a maioria das características apresentou alta herdabilidade. O maior número de ramos floridos, período de floração, comprimento do florete, diâmetro do caule, número de folhas e comprimento das folhas foram obtidos para 'Moscou'. O maior comprimento do pedúnculo, largura da flor e período de floração foram observados no genótipo promissor 'OPRC-202'. A forma da flor era dupla em 'Cherry Nymph', 'Dancing Queen' e 'OPRC-204', miniatura em 'Baby Star' e simples (uma única flor) nos outros genótipos. Com base nos resultados, os genótipos promissores 'OPRC-202' e 'OPRC-204' têm um alto potencial para serem introduzidos como novas cultivares competitivas nos mercados doméstico e internacional. Os genótipos e cultivares promissores foram categorizados em quatro grupos. Os resultados mostraram que grande parte da diversidade das características ocorreu devido a fatores genéticos e o efeito do ambiente sobre essas características foi menor.

Palavras-chave: amarílis, diversidade genética, genótipo, herdabilidade, período de floração.

*Corresponding author: m.h.azimi58@gmail.com,mh.azimi@areeo.ac.ir 


\section{Introduction}

Amaryllis is a genus from the family Amarylidaceae and the order Asparagales. The genus contains 75 species South America (Wang et al., 2018), and its endemic species are found in Brazil. It is a bulbous plant among the top 20 popular flowers in the world. In Iran, mostly grown in the north (provinces of Mazandaran, Gilan and Golestan). Amaryllis flowering plants (Hippeastrum hybridum Hort.) are used as pot plants and cut flowers or limitedly in green spaces. In Persian, amaryllis is called Nasrin. The sale of cut amaryllis flowers in major markets of the Netherlands amounted to 72 and 35 million flowers in 2012 (Hubner, 2014). More than 300 varieties are currently registered and exported by the Netherlands, South Africa, Japan, Brazil, and the United States (Vazquez et al., 2015).

Amaryllis is a plant with a wide range of colors including red, white, pink, sandy, orange and/or with veins of different colors, but they do not occur in purple and yellow. Its big flowers and easy flowering has turned amaryllis into a popular and highly demanded flower throughout the world. The flowers are trumpet-shaped, zygomorphic, diversity in color and striping (Wang et al., 2018). It is propagated by seeds (flat and have black, papery wings), offsets, twin scaling, and tissue culture (Sultana et al., 2010). But tissue culture is better for the mass production of disease-free bulbs.

There are 300 improved cultivars of amaryllis in the world. The cultivars that are cultivated are tetraploid produced by the crossing of two native Brazilian species of $H$. reginae and $H$. vittatum (Ockenga, 2002). The Netherlands and South Africa have a 200-year history of amaryllises breeding (A. herborp), and conducted a breeding program with a 15 -year perspective to improve heat resistance and produce new florets (Meerow, 2009). Tombolato and Castro (1989) produced tetraploid cultivars of 'Red Lion' and 'Apple Blossom' by controlled pollination.

Studies have been conducted on morphological attributes of native bulbous plants of Iran including daffodils (Chehrazi et al., 2007), irises (Azimi et al., 2012; 2018), gladiolus (Azimi, 2020a; 2020b; 2020c; Azimi et al., 2020), cyclamen (Naderi et al., 2016), and Fritillaria (Momeni et al., 2013).

Most breeding programs emphasize improving ornamental properties, color, size, flower shape, plant height, growth form, and sensitivity to light quality and quantity (Silva, 2004), and produce new hybrids with probable potential of commercial importance in the ornamental plants (Azimi, 2020c). The main goal in the management of a germplasm is to collect and identify its diverse forms (Khadari et al., 2003). Genetic diversity is of crucial importance for parent selection in breeding programs. Genetic diversity can be examined by morphological, molecular and biochemical methods (Krichen et al., 2012).

As the first markers, morphological traits can contribute to utilizing genetic diversity in breeding programs (Fu et al., 2008; Shao et al., 2010). Optimal morphological traits are the first criterion for the selection of a suitable germplasm. Breeders usually employ morphological traits to describe and preliminarily categorize a germplasm for the selection of valuable genetic resources for their breeding programs (Krichen et al., 2012). Hippeastrum euaniae is white or cream in color and is used as a parent to change flower color. Recently, yellow flowers were produced, but their color was not stable and the flowers were not big enough. Self-incompatibility may be tackled by embryo culture techniques or other biotechnological methods. The commercial breeding of tetraploid populations of amaryllis has an intensive history so that the hybrids enjoy optimal traits in terms of flower size and capsule number (Bell, 1973; 1977). Male-sterile triploid generations are the result of crossing between diploid and tetraploid species. Self-incompatibility happens in most diploid species and hybrids, which finally change into tetraploids (Bell, 1973; 1977). Moura et al. (2010) studied bulb traits and yields of amaryllis (Hippeastrum hybridum Hort.) in Santo Antonio de Posse, São Paulo State, Brazil aimed at its commercial production, they reported a good result of yield.

In greenhouse conditions, the acceleration or delay of development stages of plants are influenced more by genetic factors than by environmental factors. Therefore, it is of crucial importance to understand the quantitative and qualitative yield of different cultivars of amaryllis. The present research was conducted to explore genetic potentials and assess major commercial traits to introduce amaryllis cultivars with superior quantitative and qualitative yields to the production sector and for the use in breeding programs.

\section{Material and Methods}

To assess the quantitative and qualitative yield of amaryllis (Hippeastrum hybridum Hort.), the study used 10 commercial cultivars and 6 promising genotypes (Figure 1 ) in a single growth cycle. The promising genotypes were produced by pollinating imported cultivars in a five-year period in Iran (all promising genotypes were named based on the name of the institute, i.e. 'OPRCn' where ' $n$ ' refers to the numerical identifier for the promising genotypes). The research was based on a randomized complete block design with three replications and nine bulbs for each replication, conducted in the research greenhouse of the Ornamental Plants Research Center Mahallat, Iran (Lat. $33^{\circ} 53^{\prime}$ N., Long. $50^{\circ} 29^{\prime}$ E., Alt. $1732 \mathrm{~m}$ ). The growth cycle was $80 \pm 10$ days from February to June of 2018. The circumference of the bulbs size was considered to be $19 \pm$ $2 \mathrm{~cm}$. The bulbs were planted in $3-\mathrm{L}$ pots containing $40 \%$ perlite, $10 \%$ peat moss, and $50 \%$ cocopeat in the greenhouse at $25 \pm 4{ }^{\circ} \mathrm{C}$ and $70 \% \pm 5 \%$ humidity. The plants were fed by a solution with $1.6 \mathrm{dS} \mathrm{m}^{-1}$ electrical conductivity and $\mathrm{pH} 6.5 \pm 0.2$ as required by the plants. The nutrient solution used in the hydroponic system was composed of $64 \mathrm{mg} \mathrm{L}^{-1}$ $\mathrm{N}\left(10 \mathrm{mg} \mathrm{L}^{-1} \mathrm{NH}_{4}-\mathrm{N}, 54 \mathrm{mg} \mathrm{L}^{-1} \mathrm{NO}_{3}-\mathrm{N}\right), 45 \mathrm{mg} \mathrm{L}^{-1} \mathrm{P}, 239$ $\mathrm{mg} \mathrm{L}^{-1} \mathrm{~K}, 31 \mathrm{mg} \mathrm{L}^{-1} \mathrm{Mg}, 59 \mathrm{mg} \mathrm{L}^{-1} \mathrm{~S}, 1.680 \mathrm{mg} \mathrm{L}^{-1} \mathrm{Fe}$, $0.400 \mathrm{mg} \mathrm{L}^{-1} \mathrm{Mn}, 0.500 \mathrm{mg} \mathrm{L}^{-1} \mathrm{~B}, 0.030 \mathrm{mg} \mathrm{L}^{-1} \mathrm{Cu}$, and $0.050 \mathrm{mg} \mathrm{L}^{-1}$ Mo (Wahome et al., 2010). 


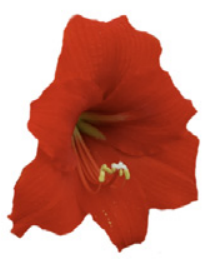

OPRC-201

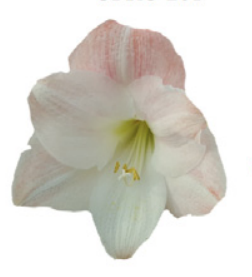

OPRC-205
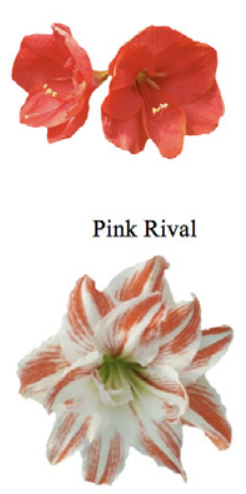

Dancing Queen

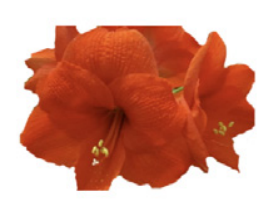

OPRC-202

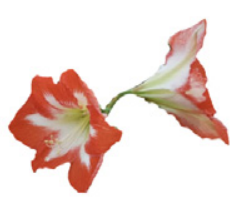

OPRC-206

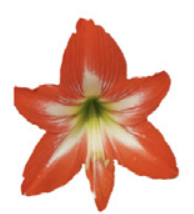

Baby Star

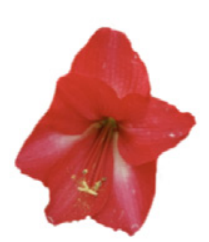

Hercules

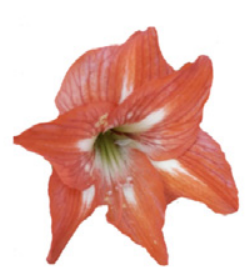

OPRC-203

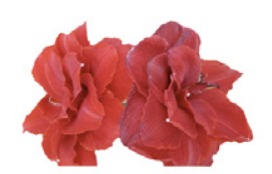

Cherry Nymph
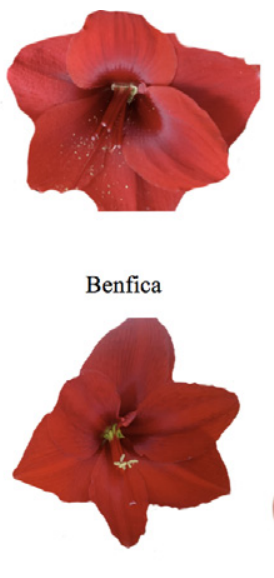

Ferrari

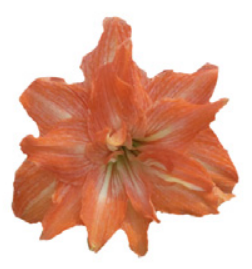

OPRC-204

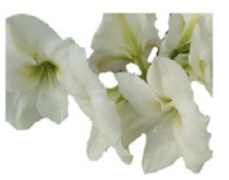

Moscow

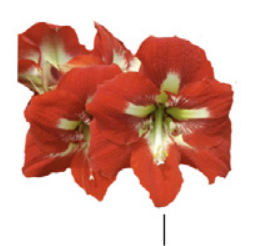

Barbados

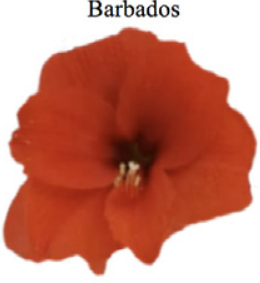

Red Lion

Figure 1. Ten commercial cultivars and six promising genotypes of Hippeastrum hybridum

At the flowering stage, 11 quantitative traits were recorded including the number of flowering branches, flowering period (day), plant height $(\mathrm{cm})$, floret width $(\mathrm{cm})$, floret length $(\mathrm{cm})$, floret number per branch, leaf number, leaf length $(\mathrm{cm})$, leaf width $(\mathrm{cm})$, stalk diameter $(\mathrm{mm})$, and peduncle length $(\mathrm{cm})$ measured by a digital caliper and ruler.

Six qualitative traits that were assessed included flower color, flower color distribution: (uniform, reined, flamed, picoted, spotted band, star-shape band), flower type: (miniature, simple, double), flower: form on frontal view (round, triangle, star-shape), flower: sepals and Petals (isomorphic, heteromorphic), flower: sepal and petal (smooth, corrugated, slightly corrugated, very corrugated), and overlapping of tepals (weak, medium, strong) based on the guideline of the International Union for the Protection of New Varieties of Plants (UPOV, 2001; Antonio et al., 2003).

The broad sense heritability, variances and phenotypic, genetic and environmental variability coefficients were calculated based on the methods of Santos et al. (2011):

Mse $=$ Mean square error, Mst $=$ Mean square treatment, $\mathrm{R}=$ Replication, $\delta^{2} \mathrm{ph}=$ Phenotypic variance, $\delta^{2} \mathrm{~g}=$ Genotypic variance, $\delta^{2} \mathrm{e}=$ Environmental Variance, $\mu=$ Grand mean of a character, and $\mathrm{h}_{\mathrm{B}}^{2}=$ Heritability in broad sense.

Genetic Coefficient of Variation (GCV): $\left(\sqrt{ } \delta_{\delta} / \mu\right) \times 100$

Phenotypic Coefficient of Variation (PCV): $(\sqrt{\mathrm{ph}} / \mu) \times 100$

Environmental Coefficient Variation $(\mathrm{ECV}):\left(\sqrt{\delta_{\mathrm{e}}^{\text {ph }}} / \mu\right) \times 100$ Genetic Variance $\left(\delta_{\mathrm{g}}^{2}\right):\left(\mathrm{MS}_{\mathrm{t}}-\mathrm{MS}_{\mathrm{e}}\right) / \mathrm{r}$

Phenotypic Variance $\left(\delta^{2}{ }_{\mathrm{ph}}\right): \delta^{2}+\delta^{2}{ }_{\mathrm{e}}$

Environmental Variance $\left(\delta_{\mathrm{e}}^{2}\right): \delta^{\mathrm{g}}{ }_{\mathrm{ph}}^{\mathrm{e}} \delta^{2} \mathrm{~g}$

Estimation of heritability: $\mathrm{h}_{\mathrm{B}}^{2}=\delta_{\mathrm{g}}{ }^{\mathrm{ph}} /{ }^{\mathrm{g}}{ }^{2}$

Genetic advance $=$ heritability $\times \mathrm{K} \times \frac{\text { root of phenotypic variance }}{\text { mean of trait }} \times 100$

in which $K$ is the selection severity (1.06 at the $5 \%$ level).

Statistical analyses included descriptive statistics, analysis of variance, means comparison by Duncan's multiple range test, cluster analysis Ward method basis on quantitative traits, and using UPGMA method, Pierson correlation coefficient, and principal component analysis with the SAS software package. 


\section{Results and Discussion}

The results of analysis of variance (ANOVA) revealed significant differences in the recorded traits among the genotypes, reflecting extensive diversity of all traits in the genotypes of amaryllis. The range of coefficient of variations $(\mathrm{CV})$ was $4.13 \%-24.91 \%$ for the traits. The highest CV (24.91\%) was related to peduncle length and the lowest (4.13\%) to flowering period (Table 1).

The results indicated that among 16 genotypes, 'Moscow' had the highest number of flowering branches (3 stalks), differing from the other cultivars significantly. The lowest number of 1.33 stalks observed in 'Hercules', 'Ferrari', and 'OPRC-206' (Table 2).

Cultivars with more flowering stalks (more than two) are preferred in commercial markets. It was found that over half of the genotypes produced two or more flowering branches, which can be considered in breeding and production programs. Demand in the trade of ornamental plants is higher for flowering plants with higher flower yield and quality (Chis et al., 2011).

Flowering period ranged from 10 to 20 days. The longest period was 20 days for 'Moscow' and 'OPRC-202' and the shortest was 10 days for 'OPRC-206' (Table 2). Most cultivars had flowering periods of longer than 15 days. The length of flowering period is influenced by pre- and postharvest factors. The quality and length of this period depends on planting conditions and post-harvest handling conditions (Azimi, 2020a). A major trait of cut and pot flowers is flowering period or vase life. Cultivars with longer flowering period are more interested by breeders and florists.

'Ferrari' and 'Dancing Queen' exhibited the highest and lowest plant height of 63.33 and $27.00 \mathrm{~cm}$, respectively (Table 2). Cultivars with a plant height of over $50 \mathrm{~cm}$ ('Pink Rival', 'Baby Star', 'Benfica', 'Hercules', 'Ferrari', 'OPRC-201', 'OPRC-204', and 'OPRC-205') can be used as cut flower and the other cultivars as pot flower. Flowering stalk length is a major characteristic for the marketability of cut flowers. This trait depends on cultivar, season, and perimeter temperature (John and Wilkens, 2004; Karavadia and Dhaduk, 2002). Plant height of a cut flower is a very important trait in its grading along with flower size. Research shows that the higher the plant height is, the larger the dimension and number of leaves and relevant reproductive parts will be.

The height of ornamental plants is an invaluable property of its appearance that not only influences its physiological traits but also increases their resistance during transportation from farms to markets and thickness of stem (Azimi et al., 2012). However, it should also be noted that compressed and dwarf flowers have recently drawn the attention of consumers.
The results showed that 'OPRC-202' and 'Moscow' had the highest floret width and length of 23.66 and $22.00 \mathrm{~cm}$, respectively. The lowest ones $(10.66 \mathrm{~cm})$ were observed in 'OPRC-206' (Table 2). Presently, consumers prefer both large and small flowers. But, flowers with larger florets are more interested in flower and plant markets (Moradi-Ashur, 2009). In some flowers like cyclamen, the focus is on flower properties and cyclamens produce flowers in different forms and sizes (Anderson, 2007). But amaryllis is an exception.

'Hercules' exhibited the highest number of florets per branch (5.33), while the lowest one was observed in 'Barbados' (3.66 florets), 'Dancing Queen' (3.66 florets), and 'OPRC-206' (3.33 florets) (Table 2). Floret number is a major trait for cut and pot flowers. Cultivars with higher floret number are more attractive, so they can be used in breeding programs. The number of inflorescence florets reduces with the decrease in the size of underground organs significantly. More floret production is caused by less intensive competition of plants over water, minerals, nutrients, and radiation (Mojiri and Arzani, 2003; Azimi, 2020a). Similar results have been reported by Padaganur et al. (2005), Khalaj and Edrisi (2013) for tuberoses. Floret number is an important trait because as the number of flowers increases, vase life, beauty and importance degree (excellent, first-class, and secondclass) of the cultivars will increase (Azimi, 2020b).

Based on the results, the highest number of leaves was 9.33 observed in 'Moscow', differing from the other cultivars significantly. The lowest number was 3.33 in 'OPRC-206' (Table 2). With respect to leaf length and width, the highest were $68.33 \mathrm{~cm}$ in 'Moscow' and $7.50 \mathrm{~cm}$ in 'Red Lion' and the lowest were 11.08 and $3.66 \mathrm{~cm}$ in 'Dancing Queen', respectively (Table 2). So, cultivars with higher leaf area exhibit better quantitative and qualitative parameters. The expansion of leaf area increases photosynthesis and contributes to the accumulation of more carbohydrates (Azimi et al., 2018; Azimi, 2020c). The increase in leaf area improves cut flower length, flower size, and its quality. Mateus et al. (2010) reported that leaf area of amaryllis amounted to $3102.65 \mathrm{~cm}^{2}$ in a 420-day growth cycle.

The highest stem (stalk) diameter of $40.57 \mathrm{~mm}$ was obtained from 'Moscow' and the lowest of $16.80 \mathrm{~mm}$ from 'Dancing Queen' (Table 2). Stalk diameter is a key trait of cut and pot flowers that is considered by breeders and growers. This trait is a precious property for cut flowers and improves their resistance during transportation from farms to markets (Azimi et al., 2012).

The highest and lowest peduncle diameters were 8.16 and $2.33 \mathrm{~cm}$ observed in 'OPRC-202' and 'Barbados', respectively (Table 2). 
Table 1. Analysis of variance in the evaluated Hippeastrum hybridum genotypes and cultivars.

\begin{tabular}{|c|c|c|c|c|c|c|c|c|c|c|c|c|}
\hline \multirow[b]{2}{*}{ S.O.V } & \multirow[b]{2}{*}{ df } & \multicolumn{11}{|c|}{$\mathbf{m s}$} \\
\hline & & $\begin{array}{c}\text { Number of } \\
\text { flowering } \\
\text { branches }\end{array}$ & $\begin{array}{c}\text { Flowering } \\
\text { period }\end{array}$ & Plant height & Floret width & $\begin{array}{l}\text { Floret } \\
\text { length }\end{array}$ & $\begin{array}{c}\text { Number of } \\
\text { florets per } \\
\text { branch }\end{array}$ & $\begin{array}{c}\text { Number of } \\
\text { leaves }\end{array}$ & Leaf length & Leaf width & $\begin{array}{c}\text { Stem } \\
\text { diameter }\end{array}$ & $\begin{array}{l}\text { Length of } \\
\text { peduncle }\end{array}$ \\
\hline Block & 2 & $0.14^{\mathrm{ns}}$ & $0.56^{\mathrm{ns}}$ & $22.42^{\text {ns }}$ & $0.46^{\mathrm{ns}}$ & $1.47^{\mathrm{ns}}$ & $0.005^{\mathrm{ns}}$ & $0.39^{\mathrm{ns}}$ & $4.72^{\mathrm{ns}}$ & $0.57^{\mathrm{ns}}$ & $18.18^{\mathrm{ns}}$ & $3.38^{\mathrm{ns}}$ \\
\hline Treat & 15 & $0.70^{* *}$ & $18.73^{* *}$ & $268.15^{* *}$ & $27.51^{* *}$ & $30.77^{* *}$ & $0.76^{*}$ & $5.49^{* *}$ & $582.13^{* *}$ & $3.276^{* *}$ & $97.85^{* *}$ & $8.75^{* *}$ \\
\hline Error & 30 & 0.16 & 0.40 & 19.28 & 2.83 & 2.44 & 0.43 & 1.14 & 18.06 & 0.51 & 4.61 & 1.20 \\
\hline $\mathrm{Cv}(\%)$ & - & 22.10 & 4.13 & 8.86 & 10.88 & 9.71 & 16.09 & 21.18 & 9.72 & 12.12 & 8.35 & 24.91 \\
\hline
\end{tabular}

** and *: Significant at $1 \%$ and $5 \%$ probability level respectively

Table 2. Mean squares of traits in Hippeastrum hybridum cultivars (1-10) and genotypes (11-16).

\begin{tabular}{|c|c|c|c|c|c|c|c|c|c|c|c|c|}
\hline Row & Cultivar/genotype & $\begin{array}{c}\text { Number of } \\
\text { flowering } \\
\text { branches }\end{array}$ & $\begin{array}{c}\text { Flowering } \\
\text { period (day) }\end{array}$ & $\begin{array}{c}\text { Plant } \\
\text { height }(\mathrm{cm})\end{array}$ & $\begin{array}{c}\text { Floret } \\
\text { width }(\mathrm{cm})\end{array}$ & $\begin{array}{c}\text { Floret } \\
\text { length } \\
\text { (cm) }\end{array}$ & $\begin{array}{c}\text { Number of } \\
\text { florets per } \\
\text { branch }\end{array}$ & $\begin{array}{l}\text { Number } \\
\text { of leaves }\end{array}$ & $\begin{array}{c}\text { Leaf } \\
\text { length } \\
(\mathrm{cm})\end{array}$ & $\begin{array}{c}\text { Leaf } \\
\text { width } \\
(\mathrm{cm})\end{array}$ & $\begin{array}{c}\text { Stem } \\
\text { diameter } \\
(\mathbf{m m})\end{array}$ & $\begin{array}{l}\text { Length of } \\
\text { peduncle } \\
\text { (cm) }\end{array}$ \\
\hline 1 & Cherry Nymph & $1.00 \mathrm{~d}$ & $14.66 \mathrm{de}$ & $47.00 \mathrm{ef}$ & $16.16 \mathrm{cde}$ & $17.5 b$ & $3.33 \mathrm{c}$ & $4.00 \mathrm{c}$ & $39.83 \mathrm{~cd}$ & $5.33 \mathrm{de}$ & $26.66 \mathrm{bcd}$ & $4.5 \mathrm{bc}$ \\
\hline 2 & Moscow & $3.00 \mathrm{a}$ & $20.00 \mathrm{a}$ & $48.33 \mathrm{def}$ & $16.33 b$ & $22.00 \mathrm{a}$ & $5.00 \mathrm{ab}$ & $9.33 \mathrm{a}$ & $68.33 a$ & $7.00 \mathrm{abc}$ & $40.57 \mathrm{a}$ & $8.00 \mathrm{a}$ \\
\hline 3 & Pink Rival & $2.33 \mathrm{ab}$ & $17.00 \mathrm{~b}$ & $55.66 \mathrm{abcd}$ & $15.00 \mathrm{cdef}$ & $16.33 b c$ & $4.00 \mathrm{bc}$ & $6.33 b$ & $44.66 \mathrm{bcd}$ & 7.33ab & $28.36 \mathrm{bc}$ & $2.83 \mathrm{~cd}$ \\
\hline 4 & Baby Star & $2.00 \mathrm{bc}$ & $12.00 \mathrm{f}$ & $52.00 \mathrm{cde}$ & $12.00 \mathrm{fg}$ & $11.5 \mathrm{de}$ & $4.00 \mathrm{bc}$ & $4.66 b c$ & $44.66 \mathrm{bcd}$ & $5.33 \mathrm{de}$ & $23.75 \mathrm{def}$ & $5.5 b$ \\
\hline 5 & Benfica & $2.00 \mathrm{bc}$ & $15.00 \mathrm{cde}$ & $56.00 \mathrm{abcd}$ & $15.66 \mathrm{cde}$ & $16.83 b$ & $4.33 b c$ & $5.00 \mathrm{bc}$ & $47.66 b c$ & $6.50 \mathrm{abcd}$ & $27.11 \mathrm{~cd}$ & $3.83 \mathrm{bcd}$ \\
\hline 6 & Barbados & $2.00 \mathrm{bc}$ & $14.00 \mathrm{e}$ & $43.00 \mathrm{fg}$ & 13.66defg & $13.66 \mathrm{~cd}$ & $3.66 \mathrm{c}$ & $3.66 \mathrm{c}$ & $13.33 \mathrm{e}$ & $4.50 \mathrm{ef}$ & $17.31 \mathrm{~g}$ & $2.33 d$ \\
\hline 7 & Dancing Queen & $2.00 \mathrm{bc}$ & $14.00 \mathrm{e}$ & $27.00 \mathrm{~h}$ & $13.00 \mathrm{efg}$ & $11.33 \mathrm{de}$ & $3.66 \mathrm{c}$ & $3.66 \mathrm{c}$ & $11.08 \mathrm{e}$ & $3.66 \mathrm{f}$ & $16.80 \mathrm{~g}$ & $3.16 \mathrm{~cd}$ \\
\hline 8 & Hercules & $1.33 \mathrm{~cd}$ & $15.00 \mathrm{cde}$ & $53.33 \mathrm{bcde}$ & $14.83 \mathrm{cdef}$ & $15.5 b c$ & $5.33 \mathrm{a}$ & $5.33 b c$ & $49.66 \mathrm{~b}$ & $5.33 \mathrm{de}$ & $27.09 \mathrm{bcd}$ & $5.83 \mathrm{~b}$ \\
\hline 9 & Ferrari & $1.33 \mathrm{~cd}$ & $15.00 \mathrm{cde}$ & $63.33 \mathrm{a}$ & $16.25 \mathrm{cde}$ & $17.33 b$ & $4.5 \mathrm{abc}$ & $4.50 \mathrm{bc}$ & $49.00 \mathrm{~b}$ & $7.50 \mathrm{a}$ & $28.13 b c$ & $3.03 \mathrm{~cd}$ \\
\hline 10 & Red Lion & $1.66 \mathrm{bcd}$ & $15.5 \mathrm{~cd}$ & $48.03 \mathrm{def}$ & $14.06 \mathrm{cdef}$ & $16.10 b c$ & $4.00 \mathrm{bc}$ & $4.5 b c$ & $46.66 b c$ & $7.25 \mathrm{ab}$ & $28.73 b c$ & $4.06 \mathrm{bcd}$ \\
\hline 11 & OPRC-201 & $2.00 \mathrm{bc}$ & $16.00 \mathrm{bc}$ & $59.00 \mathrm{abc}$ & $14.66 \mathrm{cdef}$ & $16.33 b c$ & $4.00 \mathrm{bc}$ & $5.00 \mathrm{bc}$ & $38.33 d$ & 6.33abcd & $26.06 \mathrm{cde}$ & $4.33 \mathrm{bcd}$ \\
\hline 12 & OPRC-202 & $2.32 \mathrm{ab}$ & $20.00 \mathrm{a}$ & $37.66 \mathrm{~g}$ & $23.66 \mathrm{a}$ & $21.33 \mathrm{a}$ & $4.33 b c$ & $5.66 b c$ & $52.33 b$ & $5.5 \mathrm{de}$ & $30.23 b$ & $8.16 \mathrm{a}$ \\
\hline 13 & OPRC-203 & $1.66 \mathrm{bcd}$ & $17.00 \mathrm{~b}$ & 49.66def & $16.83 \mathrm{bcd}$ & $18.16 b$ & $4.00 \mathrm{bc}$ & $5.00 \mathrm{bc}$ & $49.00 \mathrm{~b}$ & $5.66 \mathrm{cde}$ & $27.08 \mathrm{bcd}$ & $4.00 \mathrm{bcd}$ \\
\hline 14 & OPRC-204 & $1.66 \mathrm{bcd}$ & $15.00 \mathrm{cde}$ & $61.00 \mathrm{ab}$ & $14.33 \mathrm{cdef}$ & $15.33 b c$ & $4.00 \mathrm{bc}$ & $4.66 b c$ & $51.33 b$ & $5.83 \mathrm{cde}$ & $20.56 f g$ & $3.16 \mathrm{~cd}$ \\
\hline 15 & OPRC-205 & $2.00 \mathrm{bc}$ & $15.00 \mathrm{cde}$ & $52.66 \mathrm{cde}$ & $17.33 b c$ & $17.83 b$ & $3.66 \mathrm{c}$ & $5.33 b c$ & $48.33 b$ & $6.00 \mathrm{bcd}$ & $22.54 \mathrm{ef}$ & $3.33 \mathrm{~cd}$ \\
\hline 16 & OPRC-206 & $1.33 \mathrm{~cd}$ & $10.00 \mathrm{~g}$ & $38.66 \mathrm{~g}$ & $10.66 \mathrm{~g}$ & $10.66 \mathrm{e}$ & $3.33 \mathrm{bc}$ & $4.00 \mathrm{c}$ & $45.00 \mathrm{bcd}$ & $5.66 \mathrm{cde}$ & $20.33 \mathrm{fg}$ & $4.5 b c$ \\
\hline
\end{tabular}

Numbers followed by the same letter are not significantly different in $5 \%$. 


\section{Correlation of quantitative traits}

The coefficients of correlation for quantitative traits (Table 3) showed that the highest positive and significant correlations were between floret length and floret width $(\mathrm{r}=+0.90)$, between floret length and flowering period $(\mathrm{r}=+0.84)$, and between floret width and flowering period $(\mathrm{r}=+0.80)$. The weakest correlations were between peduncle length and leaf width $(\mathrm{r}=-0.03)$ and between peduncle length and plant height $(r=-0.27)$, which were insignificant.

Table 3. Correlation of quantitative traits in Hippeastrum hybridum genotypes and cultivars

\begin{tabular}{|c|c|c|c|c|c|c|c|c|c|c|c|}
\hline Characters & 1 & 2 & 3 & 4 & 5 & 6 & 7 & 8 & 9 & 10 & 11 \\
\hline $\begin{array}{l}\text { Number of } \\
\text { flowering } \\
\text { branches }\end{array}$ & 1.00 & & & & & & & & & & \\
\hline $\begin{array}{c}\text { Flowering } \\
\text { period }\end{array}$ & $0.53 * *$ & 1.00 & & & & & & & & & \\
\hline Plant height & -0.07 & 0.09 & 1.00 & & & & & & & & \\
\hline Floret width & $0.36^{*}$ & $0.80 * *$ & 0.02 & 1.00 & & & & & & & \\
\hline Floret length & $0.35^{*}$ & $0.84 * *$ & 0.24 & $0.90 * *$ & 1.00 & & & & & & \\
\hline $\begin{array}{c}\text { Number of } \\
\text { florets per } \\
\text { branch }\end{array}$ & 0.02 & 0.18 & $0.30 *$ & 0.20 & $0.31 *$ & 1.00 & & & & & \\
\hline $\begin{array}{c}\text { Number of } \\
\text { leaves }\end{array}$ & $0.53 * *$ & $0.57 * *$ & 0.23 & $0.41 * *$ & $0.55^{* *}$ & $0.47^{* *}$ & 1.00 & & & & \\
\hline Leaf length & 0.15 & $0.41 * *$ & $0.48^{* *}$ & $0.44 * *$ & $0.59 * *$ & $0.40 * *$ & $0.62 * *$ & 1.00 & & & \\
\hline Leaf width & 0.23 & $0.33 *$ & $0.57 * *$ & 0.22 & $0.43^{* *}$ & 0.19 & $0.38 * *$ & $0.61 * *$ & 1.00 & & \\
\hline Stem diameter & $0.41 * *$ & $0.68^{* *}$ & $0.26^{*}$ & $0.55^{* *}$ & $0.72 * *$ & $0.34^{*}$ & $0.66^{* *}$ & $0.71 * *$ & $0.56^{* *}$ & 1.00 & \\
\hline $\begin{array}{l}\text { Length of } \\
\text { peduncle }\end{array}$ & $0.33^{*}$ & $0.41 * *$ & $-0.27^{*}$ & $0.44 * *$ & $0.40 * *$ & 0.19 & $0.42 * *$ & $0.45^{* *}$ & -0.03 & $0.60 * *$ & 1.00 \\
\hline
\end{tabular}

** and *: significant at $1 \%$ and $5 \%$ respectively

The results showed that floret width and flowering period were increased with the increase in floret length. It is important for breeding programs to study the correlation of flower components and flowering period. This shows the superiority of simultaneous selection for more than one trait. Understanding the relationships of different traits plays a key role in the development of breeding programs for yield improvement because the selection of a single trait without considering the other traits will not yield optimal results. So, breeding programs should consider the correlation of traits (Karami et al., 2005).

\section{Grouping of genotypes}

The grouping of genotypes and cultivars by Ward's method showed that by drawing of cut-off line on a scale of +8 , the dendrogram (the confirmation of function decomposition) was divided into four groups (Figure $2)$. Group 1 was composed of two sub-groups. The first sub-group included 'Cherry Nymph', 'Pink Rival',
'Benfica', 'Barbados', 'OPRC-205', 'Hercules', 'Ferrari', 'Red Lion', and 'OPRC-204', and the second sub-group included 'OPRC-203'. Two cultivars of 'Baby Star' and 'OPRC-206' were placed in Group 2. Group 3 contained 'OPRC-201' and 'OPRC-202'. They outperformed other genotypes in most traits, so they were placed in a separate group. Group 4 contained 'Moscow' and 'Dancing Queen' (Figure 1). Selection in breeding requires genetic diversity. As genetic diversity is increased in a population, the range of selection expands. A grouping of progenies based on seed properties in gladiolus (Azimi, 2020c) showed that the progenies of the crossing of gladiolus cultivars outperformed the other progenies in most traits. They were placed in different groups (Figure 2).

\section{Principal component analysis (PCA)}

The results of analysis by the Varimax rotation revealed that the first six factors accounted for $88.60 \%$ of the total variance (Table 4). 


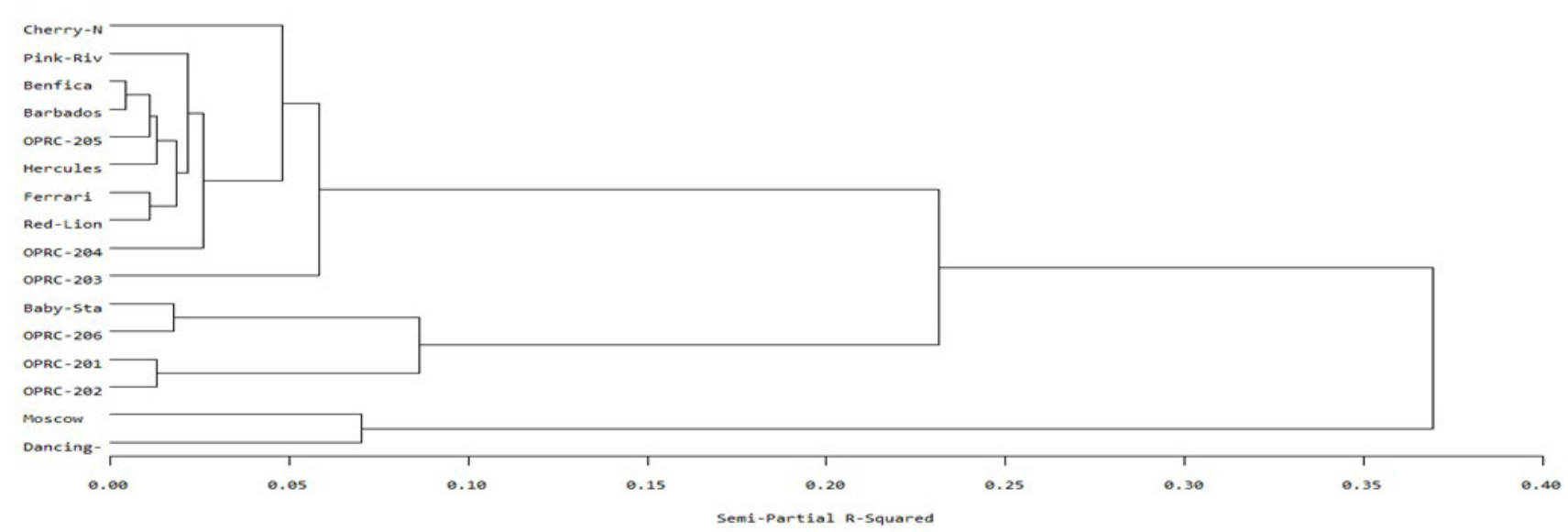

Figure 2. Dendrogram representing Hippeastrum hybridum samples according to their morphological attributes using Ward's method. Values on the top of figure $(0-40)$ are the rescaled differences of studied samples generated by SAS software.

The first factor captured $28.60 \%$ of the variance. In this factor, the traits of flowering period, floret width, floret length, and stem diameter had the highest positive factor coefficients. This factor was named floret factor. The second factor accounted for $13.10 \%$ of the variance in which the traits of stalk diameter and peduncle length showed the highest positive coefficients and plant height and leaf width had the highest negative coefficients. The third factor captured $12.90 \%$ of the variance. The traits of leaf length and width had the highest positive coefficients and peduncle length had the highest negative coefficient. This factor is called leaf factor. The fourth factor captured $11.50 \%$ of the variance. The traits of flowering stalk number, flowering period, and leaf number had the highest positive coefficients and plant height, floret number per branch, and leaf length had the highest negative coefficient. The fifth factor accounted for $11.30 \%$ of the variance (Table 4 ). Plant height and leaf length had the highest positive coefficient and the number of flowering stalks, floret width, and peduncle length exhibited the highest negative coefficients. The sixth factor captured $11.20 \%$ of the variance. The number of florets per branch and leaf number had the highest positive coefficients and the number of flowering stalks had the highest negative coefficient. PCA is multivariate analyses that can help amaryllis breeders determine traits that are most influential on total variance.

Estimating variance components, diversity coefficient, heritability, and genetic progress

The results of estimating variance components (Table 5), diversity coefficient, and heritability of the recorded traits indicated that the highest coefficient of genetic diversity was related to peduncle length (35.97\%) and leaf length (31.38\%) and the lowest to floret number per branch $(8.07 \%)$. The highest coefficient of phenotypic diversity was obtained from peduncle length, leaf length, and the number of flowering branches and the lowest from flowering period (Table 5).

Accordingly, the diversity in peduncle length and leaf length is mainly related to genetic factors and they are less influenced by the environment. So, selection for this trait can be effective. Overall, the coefficient of phenotypic diversity is higher than the coefficient of genetic diversity, which is related to the environmental conditions. The difference between the coefficients of phenotypic diversity and genetic diversity was very slight for most traits, reflecting that environmental effects did not manifest themselves because the cultivars of amaryllis were planted in the controlled (greenhouse) conditions. Most quantitative traits are greatly influenced by the environmental factors, so heritability estimations have turned out to be useful. It is important to study the correlation between flower components and other traits for the selection in breeding programs.

The highest broad heritability was observed in flowering period $(93.86 \%)$, leaf length $(91.24 \%)$ and stalk diameter (87.08\%) and the lowest $(20.37 \%)$ in the number of florets per branch (Table 5). The highest genetic progress was obtained for leaf length $(26.98 \%)$ and the lowest for the number of flowering branches $(0.64 \%)$ and the number of florets per branch $(0.32 \%)$ at the $\mathrm{P}<0.05$ level. Traits that are not influenced by the environmental factors show high heritability. The highest heritability in gladiolus were estimated as plant height, leaf width, leaf length, number of florets, length of spike and diameter of stem (Azimi, 2020a). 


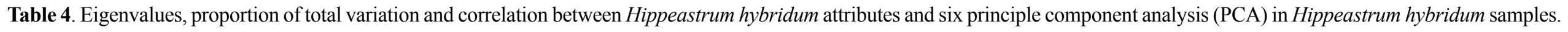

\begin{tabular}{|c|c|c|c|c|c|c|}
\hline Traits & PCA1 & PCA2 & PCA3 & PCA4 & PCA5 & PCA6 \\
\hline Number of flowering branches & 0.23 & 0.12 & 0.09 & 0.94 & -0.05 & -0.03 \\
\hline Flowering period & 0.80 & 0.14 & 0.13 & 0.28 & 0.03 & 0.03 \\
\hline Plant height & 0.04 & -0.15 & 0.28 & -0.05 & 0.92 & 0.15 \\
\hline Floret width & 0.95 & 0.17 & 0.04 & 0.12 & -0.03 & 0.07 \\
\hline Floret length & 0.89 & 0.15 & 0.20 & 0.09 & 0.13 & 0.13 \\
\hline Number of florets per branch & 0.11 & 0.08 & 0.06 & -0.02 & 0.13 & 0.96 \\
\hline Number of leaves & 0.27 & 0.20 & 0.16 & 0.31 & 0.10 & 0.28 \\
\hline Leaf length & 0.29 & 0.34 & 0.38 & -0.02 & 0.30 & 0.19 \\
\hline Leaf width & 0.17 & -0.04 & 0.91 & 0.11 & 0.29 & 0.06 \\
\hline Stem diameter & 0.44 & 0.44 & 0.37 & 0.17 & 0.14 & 0.15 \\
\hline Length of peduncle & 0.25 & 0.92 & -0.05 & 0.14 & -0.18 & 0.08 \\
\hline Eigenvalue variance (\%) & 28.6 & 13.1 & 12.9 & 11.5 & 11.3 & 11.2 \\
\hline Cumulative variation (\%) & 28.60 & 41.70 & 54.60 & 66.10 & 77.40 & 88.6 \\
\hline
\end{tabular}

Table 5. Genotypic variances, phenotypic traits and heritability in Hippeastrum hybridum

\begin{tabular}{|c|c|c|c|c|c|c|c|c|c|c|c|c|}
\hline \multicolumn{2}{|c|}{ S.O.V } & \multirow{2}{*}{$\begin{array}{c}\begin{array}{c}\text { Number of } \\
\text { flowering } \\
\text { branches }\end{array} \\
0.18\end{array}$} & \multirow{2}{*}{$\begin{array}{c}\begin{array}{c}\text { Flowering } \\
\text { period }\end{array} \\
6.11\end{array}$} & \multirow{2}{*}{$\begin{array}{c}\text { Plant height } \\
82.96\end{array}$} & \multirow{2}{*}{$\begin{array}{c}\text { Floret } \\
\text { width }\end{array}$} & \multirow{2}{*}{$\begin{array}{c}\text { Floret } \\
\text { length }\end{array}$} & \multirow{2}{*}{$\begin{array}{c}\begin{array}{c}\text { Number } \\
\text { of florets } \\
\text { per } \\
\text { branch }\end{array} \\
0.11\end{array}$} & \multirow{2}{*}{$\begin{array}{c}\begin{array}{c}\text { Number } \\
\text { of leaves }\end{array} \\
1.45\end{array}$} & \multirow{2}{*}{$\begin{array}{c}\begin{array}{c}\text { Leaf } \\
\text { length }\end{array} \\
188.02\end{array}$} & \multirow{2}{*}{$\begin{array}{c}\begin{array}{c}\text { Leaf } \\
\text { width }\end{array} \\
0.92\end{array}$} & \multirow{2}{*}{$\begin{array}{c}\begin{array}{c}\text { Stem } \\
\text { diameter }\end{array} \\
31.08\end{array}$} & \multirow{2}{*}{$\begin{array}{r}\begin{array}{r}\text { Length of } \\
\text { peduncle }\end{array} \\
2.52 \\
\end{array}$} \\
\hline \multirow{3}{*}{ Variance } & Genotype & & & & & & & & & & & \\
\hline & Phenotypic & 0.34 & 6.51 & 102.24 & 11.06 & 11.88 & 0.54 & 2.59 & 206.08 & 1.43 & 35.65 & 3.72 \\
\hline & Environmental & 0.16 & 0.40 & 19.28 & 2.83 & 2.44 & 0.43 & 1.14 & 18.06 & 0.51 & 4.61 & 1.20 \\
\hline \multirow{3}{*}{$\begin{array}{l}\text { Coefficient of } \\
\text { variance }(\%)\end{array}$} & Genotypic & 22.93 & 16.13 & 18.39 & 18.54 & 19.08 & 8.07 & 23.89 & 31.38 & 16.32 & 21.68 & 35.97 \\
\hline & Phenotypic & 31.52 & 16.65 & 20.42 & 21.49 & 21.40 & 17.88 & 31.93 & 32.85 & 20.21 & 23.24 & 43.72 \\
\hline & Environmental & 21.61 & 4.13 & 8.87 & 10.87 & 9.70 & 15.95 & 21.18 & 9.72 & 12.06 & 8.35 & 24.84 \\
\hline \multicolumn{2}{|c|}{ Broad sense heritability (\%) } & 52.94 & 93.86 & 81.14 & 74.40 & 79.47 & 20.37 & 55.98 & 91.24 & 64.39 & 87.08 & 67.71 \\
\hline \multicolumn{2}{|c|}{ Genetic advance } & 0.64 & 4.93 & 16.90 & 5.10 & 5.64 & 0.31 & 1.86 & 26.98 & 1.59 & 10.72 & 5.18 \\
\hline
\end{tabular}


Consequently, it shows better achievement for the selection of a genetically optimal individual (Randhawa et al., 2000). Highly heritable traits can be regarded as morphological characteristics and a good choice for genetic diversity studies (Fu et al., 2008; Shao et al., 2010). The highest coefficient of phenotypic and genetic variance in gladiolus was reported for cormlet diameter and stem diameter (Moradi-Ashur, 2009). In an assessment of the traits in the first generation of German iris, Fan et al. (2014) found that petal width had the highest heritability $(91.74 \%)$. Selection for traits that have simultaneously high heritability and genetic progress can be viable (Gul et al., 2013).

\section{Assessment of qualitative traits}

The flower color ranged from red to white, pink and a combination of them. Most cultivars had a color tendency to red or a combination of red (Table 6). The color distribution in florets was uniform in 'Cherry Nymph', 'Hercules', 'Ferrari', 'Red Lion', 'OPRC-202', and 'OPRC-206' and non-uniform in other genotypes. Flower type was double in 'Cherry Nymph', 'Dancing Queen', and 'OPRC-204', miniature in 'Baby Star', and single-flower (simple) in other cultivars. Flower form on frontal view was starshaped in all cultivars. Petal and sepal shape in floret were isomorphic in 'Cherry Nymph' and heteromorphic in other cultivars. Petal and sepal status were corrugated in 'Cherry Nymph', 'Dancing Queen', and 'OPRC-204', slightly corrugated in 'Moscow', 'Pink Rival', 'Baby Star', 'Ferrari', and 'Red Lion', and smooth in other cultivars. All cultivars showed weak overlapping of petals and sepals.

Table 6. Ornamental traits in Hippeastrum hybridum genotypes and cultivars

\begin{tabular}{|c|c|c|c|c|c|c|}
\hline $\begin{array}{l}\text { Name of } \\
\text { cultivar }\end{array}$ & Flower: color & $\begin{array}{c}\text { Tepal: } \\
\text { overlapping } \\
\text { of tepals } \\
\text { (weak, } \\
\text { medium, } \\
\text { strong) }\end{array}$ & $\begin{array}{c}\text { Flower: } \\
\text { Sepal and tepal } \\
\text { (Smooth, } \\
\text { corrugated, } \\
\text { slightly } \\
\text { corrugated, } \\
\text { very corrugated }\end{array}$ & $\begin{array}{c}\text { Flower: } \\
\text { sepals } \\
\text { and Petals } \\
\text { (Isomorphic, } \\
\text { heteromorphic) }\end{array}$ & $\begin{array}{c}\text { Flower: } \\
\text { form on } \\
\text { frontal view } \\
\text { (Round, } \\
\text { riangle, } \\
\text { star-shape) }\end{array}$ & $\begin{array}{c}\text { Flower type: } \\
\text { (Miniature, } \\
\text { simple, } \\
\text { double) }\end{array}$ \\
\hline Cherry Nymph & Red & weak & corrugated & isomorphic & star-shape & double \\
\hline Moscow & White & weak & $\begin{array}{c}\text { slightly } \\
\text { corrugated }\end{array}$ & heteromorphic & star-shape & simple \\
\hline Pink Rival & Hot pink & weak & $\begin{array}{l}\text { slightly } \\
\text { corrugated }\end{array}$ & heteromorphic & star-shape & simple \\
\hline Baby Star & Red/ vein white & weak & $\begin{array}{c}\text { slightly } \\
\text { corrugated }\end{array}$ & heteromorphic & star-shape & miniature \\
\hline Benfica & Red & weak & smooth & heteromorphic & star-shape & simple \\
\hline Barbados & Red/ vein white & weak & smooth & heteromorphic & star-shape & simple \\
\hline Dancing Queen & Red/ white & weak & corrugated & heteromorphic & star-shape & double \\
\hline Hercules & Hot pink & weak & smooth & heteromorphic & star-shape & simple \\
\hline Ferrari & Red & weak & $\begin{array}{c}\text { slightly } \\
\text { corrugated }\end{array}$ & heteromorphic & star-shape & simple \\
\hline Red Lion & light red & weak & $\begin{array}{l}\text { slightly } \\
\text { corrugated }\end{array}$ & heteromorphic & star-shape & simple \\
\hline OPRC-201 & Dark red & weak & smooth & heteromorphic & star-shape & simple \\
\hline OPRC-202 & Red & weak & smooth & heteromorphic & star-shape & simple \\
\hline OPRC-203 & Light red/ red & weak & smooth & heteromorphic & star-shape & simple \\
\hline OPRC-204 & Light red/ red & weak & corrugated & heteromorphic & star-shape & double \\
\hline OPRC-205 & White/ light pink & weak & smooth & heteromorphic & star-shape & simple \\
\hline OPRC-206 & Red/ vein white & weak & smooth & heteromorphic & star-shape & simple \\
\hline
\end{tabular}




\section{Conclusions}

The cultivar Moscow outperformed the other cultivars in quantitative and qualitative traits. Among the promising genotypes, 'OPRC-202' and 'OPRC-204' had a high potential to be introduced as new and competitive cultivars in domestic and non-domestic markets. The results showed a high diversity in flower components of the cultivars, which can be used based on the taste of consumers and markets. In breeding ornamental plants, emphasis is placed on presenting more attractive species with optimal characteristics in addition to producing plants with higher quality. Today, miniature flowers are more interested. Flowering period is highly heritable with genetic progress, so it can be a good marker of parent selection in hybridization programs. Also, cultivars with high diversity and superior traits can be used in breeding programs.

\section{Author Contribution}

MHA, MKA: designing the experiments, obtaining and analyzing data and writing the scientific article.

\section{Acknowledgement}

The financial support of the Ornamental Plants Research Center is gratefully acknowledged.

\section{References}

ANDERSON, N.O. Flower Breeding and Genetics. Netherlands: Springer, 2007. p.691.

AZIMI, M.H. Assessment and ranking of new Gladiolus hybrids in Iran. Journal of Horticulture and Postharvest Research, v.3, n.2, p.235-244, 2020b. DOI: https://doi. org/10.22077/JHPR.2020.2972.1112

AZIMI, M.H. Evaluation yield and genetically factors in different cultivars of Gladiolus. Ornamental Horticulture, v.26, n.1, p.7-18, 2020a. DOI: https://doi. org/10.1590/2447-536X.v26i1.2027

AZIMI, M.H. Heterosis and genetic diversity in the crossings of Gladiolus cultivars Amsterdam and White Prosperity. Ornamental Horticulture, v.26, n.2, p.177189, 2020c. DOI: https://doi.org/10.1590/2447-536X. v26i2.2095

AZIMI, M.H.; EDRISI, B.; KHALAJ, M.A. Evaluation of genetic parameters and cormlet yield in Gladiolus offspring. Journal of Ornamental Plants, v.10, n.1, p.37-47, 2020.

AZIMI, M.H.; JOZGHASEMI, S.; BARBA-GONZALEZ, R. Multivariate analysis of morphological characteristics in Iris germanica hybrids. Euphytica, n.214, p.161, 2018. DOI: https://doi.org/10.1007/s10681-018-2239-7
AZIMI, M.H.; SADEGHIAN, S.Y.; RAZAVIAHARI, V.; KHAZAEI, F.; FATHIHAFASHJANI, A. Genetic variation of Iranian Iris species using morphological characteristics and RAPD markers. International Journal of Agriculture Sciences, v.2, n.9, p.875-889, 2012.

BELL, W.D. Double flowered Amaryllis. Proceedings of the Florida State Horticultural Society, v.90, p.121-122, 1977.

BELL, W.D. New potentials in Amaryllis breeding. Proceedings of the Florida State Horticultural Society, v.86, p.462-466, 1973.

CHEHRAZI, M.; NADERI, R.; SHAHNEJATBUSHEHRI, A.; HASANI, M.E. Study of genetic diversity of exotic and endemic Daffodils (Narcissus spp.) Using RAPD Markers. Iranian Journal of Horticultural Science and Technology, v.8, n.4, p.225-236, 2007.

CHIS, M.L.; CANTOR, M.; HARSAN, E. Realizations and new trends in breeding of Gladiolus hybridus at fruit research station Cluj. Bulletin of University of Agricultural Sciences and Veterinary Medicine Cluj-Napoca. Horticulture, v.67, n.1, p.324-329, 2011.

FAN, X.M.; ZHANG, Y.D.; YAO, W.H.; BI, Y.Q.; LIU, L.; CHEN, H.M.; KANG, M.S. Reciprocal diallel crosses impact combining ability, variance estimation, and heterotic group classification. Crop Science, v.54, p.89-97, 2014. DOI: https://doi.org/10.2135/cropsci2013.06.0393

FU, X.P.; NING, G.G.; GAO, L.P.; BAO, M.Z. Genetic diversity of dianthus accessions as assessed using two molecular marker systems (SRAPs and ISSRs) and morphological traits. Scientia Horticulture, v.117, p.263-270, 2008. DOI: https://doi.org/10.1016/j. scienta.2008.04.001

GUL, R.; KHAN, H.; BIBI, M.; AIN, Q.U.; IMRAN, B. Genetic analysis and interrelationship of yield attributing traits in Chickpea (Cicer arietinum L.). The Journal of Animal and Plant Sciences, v.23, p.521-526, 2013.

\section{HUBNER, S. International Statistics Flowers and Plants.} Hannover: Center for Business Management in Horticulture and applied research, International Association of Horticultural Producers (AIPH) in association with Union Fleurs, 2014. 190p.

JOHN, M.D.; WILKENS, H. Floriculture: Principles and Species, 2ed. Amsterdam: Pearson, 2004. 1048p.

KARAMI, E.; GHANNADHA, M.R.; NAGHAVI, M.R.; MARDI, M. An Evolution of Drought Resistance in Barley. Iranian Journal Agriculture Science, n.36, v.3, p.547-560, 2005. 
KARAVADIA, B.N.; DHADUK, B.K. Effect of spacing and nitrogen on annual chrysanthemum, Chrysanthemum coronarium cv. 'Local White'. Journal of Ornamental Horticulture, v.5, n.1, p.65-66, 2002.

KHADARI, B.; BRETON, C.; MOUTIER, N. The use of molecular markers for germplasm management in a French olive collection. Theoretical and Applied Genetics, v.106, p.521-529, 2003. DOI: https://dx.doi.org/10.1007/ s00122-002-1079-x

KHALAJ, M.A; EDRISI, B. The effect of nitrogen and planting density on growth indexes and consumption of highly concentrated elements in the Double cultivar of Polianthes tuberosa. Journal of Horticulture, n.27, v.1, p.66-59, 2013.

KRICHEN, L.; AUDERGON, J.M.; TRIFI-FARAH, $\mathrm{N}$. Relative efficiency of morphological characters and molecular markers in the establishment of an apricot core collection. Hereditas, v.149, p.163-172, 2012. DOI: https:// doi.org/10.1111/j.1601-5223.2012.02245.x

MATEUS, C.M.D.A.; PIVETTA, K.F.L.; VILLAS BOAS, R.L.; COAN, R.M.C. Growth analysis of amaryllis (Hippeastrum $x$ hybridum Hort.) grown in full sun. Revista Ceres, v.57, n.4, p.469-475, 2010. DOI: https://doi. org/10.1590/s0034-737x2010000400005

MEEROW, A.W. Tilting at windmills: 20 years of Hippeastrum breeding. Journal of Plant Science, v.57, n.4, p.303-313, 2009. DOI: 10.1560/IJPS.57.4.303

MOJIRI, A.; ARZANI, A. Effects of nitrogen rate and plant density on yield and yield components of sunflower. Journal Science and Technology Agriculture and Natural Resources, v.7, n. 2, p.115-125, 2003.

MOMENI, H.; SHIRAN, B.; KHODAMBASHI, M.; CHEGHAMIRZA, K. An Assessment of the Genetic Diversity of Imperial Crown (Fritillaria imperialis L.) Populations from Zagross Region of Iran through ISSR Markers and Morphological Traits. Iranian Journal Horticulture Science, v.44, n.1, p.61-72, 2013. DOI:10.22059/IJHS.2013.30405

MORADI-ASHUR, B. Evaluation of genetic diversity of quantitative characteristics and selection of single plants for their growth in Gladiolus grandifloras varieties. Iran: Ornamental Plants Research Center (OPRC), Horticultural Sciences Research Institute, Agricultural Research, Education and Extension Organization (AREEO), 2009, p.63.
NADERI, R.; KERMANSHAHANI, M.; FATTAHI, M.; KHALIGHI, A. Evaluating features of Cyclamen (Cyclamen persicum Mill.) progenies resulted from cross pollination. Iranian Journal of Horticultural Science, v.46, n.4. 575-589, 2016.

OCKENGA, S. Amaryllis. New York: Random House, 2002. 96p.

PADAGANUR, V.G.; MOKASHI, A.N.; PATIL, V.S. Effect of growth regulators on growth and yield of tuberose cv. Single. Karnataka Journal of Agriculture Science, v.8, n.2, p.469- 473, 2005.

RANDHAWA, S.; MUKHOPADHYAY, S.P. Promising varieties of gladiolus for commercial floriculture. Haryana Journal of Horticulture Science, n.24, v.3-4, p.197-203, 2000 .

SANTOS, E.A.; SOUZA, M.M.; ALMEIDA, A.A.F.; FREITAS, J.C.O.; LAWINSCKY, P.R. Multivariate analysis of morphological characteristics of two species of passion flower with ornamental potential and of hybrids between them. Genetics and Molecular Research, n.10, v.4, p.2457-2471, 2011. DOI: https://doi.org/10.4238/2011. October. 13.3

SHAO, Q.S.; GUO, Q.S.; DENG, Y.M.; GUO, H.P. A comparative analysis of genetic diversity in medicinal Chrysanthemum morifolium based on morphology, ISSR and SRAP markers. Biochemical Systematics and Ecology, v.38, p.1160-1169, 2010. DOI: https://doi. org/10.1016/j.bse.2010.11.002

SILVA, T.D.J.A. Ornamental Chrysanthemums: improvement by biotechnology. Plant Cell Tissue and Organ Culture, v.79, p.1-18, 2004. DOI: https://doi. org/10.1023/b:ticu.0000049444.67329.b9

SULTANA, J; SUTLANA, N; SIDDIQUE, M.N.A; ISLAM, A.K.M.A; HOSSAIN, M.; HOSSAIN, T. In vitro bulb production in Hippeastrum (Hippeastrum hybridum). Journal of Central European Agriculture, v.11, n.4, p.469-474, 2010

TOMBOLATO, A.F.C.; CASTRO, C.E.F. Research program on Hippeastrum. Herbertia, v.45, n.1-2, p.45-49, 1989.

UPOV. Guidelines for the conduct of tests for distinctness, uniformity and stability Amaryllis (Hippeastrum Herb.). Geneva: International Unionfor The Protectionof New Varieties of Plant TG/181/3, 2001. p.17. 
VAZQUEZ, C.; REED, S.T.; DUNN, C. Nitrogen Fertilization as Ammonium or Nitrate-N on Hippeastrum hybridum BulbGrowth. Agricultural Sciences, v.6, p.1547-1554, 2015. DOI: http://dx.doi.org/10.4236/ as. 2015.612148

WAHOME, P.K.; MASARIRAMBI, M.T.; SHONGWE, V.D. Evaluating different hydroponics systems for growth, flowering and quality of Gladiolus (Gladiolus grandiflorus). International Journal of Agriculture and Biology, v.12, n.5, p.649-654, 2010.
WANG, Y.; CHEN, D.; HE, X.; SHEN, J.; XIONG, M.; WANG, X.; ZHOU1, D.; WEI, Z. Revealing the complex genetic structure of cultivated amaryllis (Hippeastrum hybridum) using transcriptome-derived microsatellite markers. Scientific Reports, v.8, n.10645, p.1-12, 2018. DOI: https://doi.org/10.1038/s41598-018-28809-9 